\title{
Acute coronary syndrome: Relationship between genetic variants and TIMI risk
}

\author{
Viviane do Carmo Vasconcelos de Carvalho ${ }^{\mathrm{a}}$, Lílian Caroliny Amorim Silva ${ }^{\mathrm{a}}$, \\ Romário Martins Araújo a , Fábia Carla da Silva Soares ${ }^{\mathrm{a}}$, Maria José Ribeiro Bezerra ${ }^{\mathrm{a}}$, \\ Sávio Augusto Vieira de Oliveira ${ }^{\mathrm{a}}$, Alex José de Melo Silva ${ }^{\mathrm{a}}$, Sérgio Tavares Montenegro ${ }^{\mathrm{b}}$, \\ Roberto Pereira Werkhauser ${ }^{\mathrm{a}}$, Carlos Gustavo Régis da Silva ${ }^{\mathrm{c}}$, Adriana Vieira Gomes ${ }^{\mathrm{d}}$, \\ Clarice Neuenschwander Lins de Morais ${ }^{e}$, Silvia Maria Lucena Montenegro, ${ }^{\mathrm{a}, *}$
}

\footnotetext{
${ }^{a}$ Laboratório de Imunologia e Biologia Molecular, Departamento de Imunologia, Instituto Aggeu Magalhães, Fiocruz - PE, Av. Professor Moraes Rego, s/n, Cidade Universitária, Zipe Code: 50.740-465, Recife, PE, Brazil

${ }^{\mathbf{b}}$ Real Hospital do Coração, Real Hospital Português (RHP), Av. Gov. Agamenon Magalhães, 4760, Paissandu, Zipe Code: 52010-902, Recife, PE, Brazil

${ }^{\mathrm{c}}$ Laboratório de Biologia Parasitária, Centro de Pesquisas Gonçalo Moniz, Fiocruz-BA, R. Waldemar Falcão, 121, Candeal, Zipe Code: 40296-710, Salvador, BA, Brazil

${ }^{\mathrm{d}}$ Faculdade de Ciências Médicas - FCM, Universidade de Pernambuco - UPE, Rua Arnóbio Marques, 310, Santo Amaro, Zipe Code: 50100-130, Recife, PE, Brazil

${ }^{e}$ Laboratório de Virologia e Terapia Experimental (LaViTE), Departamento de Virologia, Instituto Aggeu Magalhães, Fiocruz - PE, Av. Professor Moraes Rego, s/n, Cidade Universitária, Zip Code: 50.740-465, Recife, PE, Brazil
}

\section{A R T I C L E I N F O}

\section{Keywords:}

Acute coronary syndrome

Genetic variants

Cytokines

Risk factors

\begin{abstract}
A B S T R A C T
Acute Coronary Syndrome (ACS) is a multifactorial disease, including the genetic factor, caused by coronary artery obstruction by atheroma. Some genetic variants have been described as risk factors for this disease. Its early diagnosis and stratification of risk of death by Thrombolysis in Myocardial Infarction (TIMI) are important. Therefore, we evaluated variants in the IL6R (c950-1722C > T), TNFa (c.-488G $>$ A), LEPR $(c .2673+1118 \mathrm{C}>\mathrm{T})$ and $I L 1 b(c .-598 \mathrm{~T}>\mathrm{C})$ genes in relation to TIMI risk, cytokine serum levels, and risk factors for ACS. We selected 200 patients with ACS, 50 without ACS from the Real Hospital Português, Recife $\mathrm{PE}$, and 295 blood donors at the Fundação de Hematologia e Hemoterapia de Pernambuco (Hemope). Variants were determined by DNA sequencing or enzymatic cleavage. Cytokine levels were measured by ELISA. The most frequent risk factors found in the patients were dyslipidemia and hypertension, this latter associated with high TIMI risk ( $\mathrm{p}=0.003)$. Genotype frequencies of IL6R and TNFa differed between patients with ACS and the blood donors ( $\mathrm{p}=0.0002$ and $\mathrm{p}=0.01$, respectively), and TNF- $\alpha$ levels differed between genotypes. The TT genotype of the $I L 6 R$ gene is as a possible protective factor for ACS because it was significantly more present in blood donors $(32.2 \%)$ than in patients with ACS (18.0\%), and was more frequent in low TIMI risk (22.9\%) than in the intermediate $(20.2 \%)$ or high $(4.9 \%)$. In patients with ACS, the TT genotype in IL6R was related to a lower concentration of c-reactive protein $(p=0.03)$ and troponin $(p=0.02)$, showing a less inflammatory reaction and tissue damage. The differences in the frequencies of variants in genes of medical interest among the groups show the importance of studies in specific populations groups to establish the relationship between genes and diseases.
\end{abstract}

\section{Introduction}

Cardiovascular diseases (DCs) are currently the leading causes of death in the world (WHO, 2016). Among them, Acute Coronary
Syndrome (ACS), which includes Acute Myocardial Infarction (AMI) and Unstable Angina (IA), is a cardiovascular disease caused by obstruction of the coronary arteries by atheromatous plaque and involves clinical symptoms compatible with acute myocardial ischemia [1,2].

\footnotetext{
* Corresponding author at: Laboratório de Imunologia e Biologia Molecular, Departamento de Imunologia, Instituto Aggeu Magalhães, Fiocruz - PE, Av. Professor Moraes Rego, s/n, Zip Code: 50.740-465, Recife, PE, Brazil.

E-mail addresses: vivicarvalho@gmail.com (V.d.C.V. de Carvalho), liliancaroli_ny@hotmail.com (L.C.A. Silva), araujo.rmartins@gmail.com (R.M. Araújo),

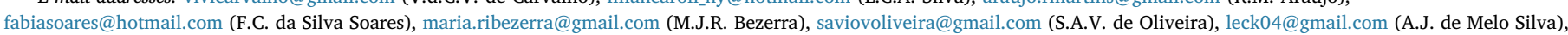

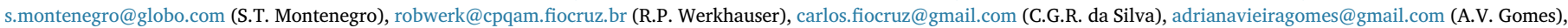
clarice@cpqam.fiocruz.br (C.N.L. de Morais), silvia@cpqam.fiocruz.br (S.M.L. Montenegro).
} 
Table 1

Genotyping conditions [16-19].

\begin{tabular}{|c|c|c|c|c|c|c|}
\hline Genes & Primers & PCR conditions & & $\begin{array}{l}\text { gment } \\
\text { Size }\end{array}$ & Genotyping & Reference \\
\hline $\begin{array}{c}I L 6 R \\
(c 950-1722 C>T)\end{array}$ & $\begin{array}{l}\text { F: 5' GTC GCT } \\
\text { TTC CCT CTC } \\
\text { CG 3' } \\
\text { R: 5' GGA } \\
\text { AAC CCC } \\
\text { AAG GCA } \\
\text { AGA GG 3' }\end{array}$ & $\left.\begin{array}{r}95^{\circ} \mathrm{C}-5 \mathrm{~min} \\
95^{\circ} \mathrm{C}-30 \mathrm{sec} \\
59^{\circ} \mathrm{C}-30 \mathrm{sec} \\
68^{\circ} \mathrm{C}-20 \mathrm{sec} \\
95^{\circ} \mathrm{C}-30 \mathrm{sec} \\
57^{\circ} \mathrm{C}-30 \mathrm{sec} \\
68^{\circ} \mathrm{C}-20 \sec \\
95^{\circ} \mathrm{C}-30 \mathrm{sec} \\
55^{\circ} \mathrm{C}-30 \sec \\
68^{\circ} \mathrm{C}-20 \sec \end{array}\right\}$ & $10 \mathrm{X}$ & $370 \mathrm{bp}$ & $\begin{array}{c}\text { Enzymatic } \\
\text { digestion - BsaHI } \\
\text { (New England } \\
\left.\text { Biolabs }{ }^{\circledR}\right)\end{array}$ & [16] \\
\hline $\begin{array}{c}T N F a \\
(c .-488 G>A)\end{array}$ & $\begin{array}{l}\text { F: 5'AGG CTT } \\
\text { GTC CCT GCT } \\
\text { ACC CCC 3' } \\
\text { R: 5' TCC TCC } \\
\text { CTG CTC CGA } \\
\text { TTC CG 3, }\end{array}$ & $\left.\begin{array}{l}95^{\circ} \mathrm{C}-5 \mathrm{~min} \\
95^{\circ} \mathrm{C}-30 \mathrm{seg} \\
65^{\circ} \mathrm{C}-30 \mathrm{seg} \\
72^{\circ} \mathrm{C}-30 \mathrm{seg} \\
72^{\circ} \mathrm{C}-2 \mathrm{~min}\end{array}\right\}$ & $-30 X$ & $363 \mathrm{bp}$ & DNA Sequencing & {$[17]$} \\
\hline $\begin{array}{c}\mathrm{LEPR} \\
(c .2673+1118 C>T)\end{array}$ & $\begin{array}{l}\text { F: 5' GCC CTT } \\
\text { CTT TCC TCA } \\
\text { AGC CTT CC } \\
\text { 3' } \\
\text { R: 5' GCT CCA } \\
\text { AAG CCA } \\
\text { GAC AAA } \\
\text { CTG GT 3', }\end{array}$ & $\left.\begin{array}{l}95^{\circ} \mathrm{C}-5 \mathrm{~min} \\
95^{\circ} \mathrm{C}-30 \mathrm{sec} \\
55^{\circ} \mathrm{C}-30 \mathrm{sec} \\
68^{\circ} \mathrm{C}-30 \mathrm{sec} \\
68^{\circ} \mathrm{C}-5 \mathrm{~min}\end{array}\right\}$ & $30 X$ & $515 \mathrm{bp}$ & DNA Sequencing & {$[18]$} \\
\hline $\begin{array}{c}I L 1 b \\
(c .-598 T>C)\end{array}$ & $\begin{array}{l}\text { F: 5' TGG CAT } \\
\text { TGA TCT GGT } \\
\text { TCA TC 3' } \\
\text { R: 5' GTT TAG } \\
\text { GAA TCT TCC } \\
\text { CAC TT 3, }\end{array}$ & $\left.\begin{array}{l}94^{\circ} \mathrm{C}-5 \mathrm{~min} \\
94^{\circ} \mathrm{C}-60 \mathrm{sec} \\
55^{\circ} \mathrm{C}-40 \mathrm{sec} \\
72^{\circ} \mathrm{C}-40 \mathrm{sec} \\
74^{\circ} \mathrm{C}-7 \mathrm{~min}\end{array}\right\}$ & $35 \mathrm{X}$ & $304 \mathrm{bp}$ & DNA Sequencing & [19] \\
\hline
\end{tabular}

ACS has a multifactorial phenotype determined by genetic factors and influenced by other risk factors, such as hypertension, diabetes, dyslipidemia, obesity and smoking. Age and gender also influence its development [3].

The identification of severity risk in ACS patients is important so that they can be benefited with a more appropriate treatment. In this sense the Thrombolysis in Myocardial Infarction (TIMI) research group proposed a rapid and practical classification that selects patients at low, moderate and high risk according to clinical data, electrocardiographic changes and biomarkers of myocardial injury, defining the best therapeutic strategy and prognostic for each case [4].

Several studies seek to describe genetic markers using molecular biology methods to identify genes that are related to coronary heart disease process and its risk factors $[5,6]$. Therefore, variants of genes involved in the atherosclerosis inflammatory response have received attention as a contribution to the development of innovative tools for diagnosis in ACS [7].

The presence of variants in some genes can alter their transcription and expression levels, generating different amounts of messenger RNA and the respective protein, contributing to the development of some pathologies, such as ACS [8]. Studies with variants in Interleukin (IL)-6 receptor (IL6R), Leptin Receptor (LEPR), Tumor Necrosis Factor-alpha (TNFa) and $I L 1 b$ [9-11], were pointed out in association with ACS, but they presented divergent results when it comes to different study populations [12-14].

Thus, the investigation of genetic variants that are related to ACS may contribute to the identification of additional risk factors and function as markers of susceptibility and prognosis in ACS development. So, the aim of this study was to evaluate the relationship between the TIMI risk score and genes variants, inflammatory markers and myocardial injury in patients with ACS.

\section{Materials and methods}

\subsection{Subjects}

In an analytical and cross-sectional study with groups comparison, 200 patients (mean age $62.0 \pm 13$ ) with ACS admitted to Real Hospital Português (RHP), in Recife - Pernambuco, Brazil from 2012 to 2015 were recruited. All of them were submitted to electrocardiogram and dosages of injury myocardial creatine kinase MB fraction (CK-MB) and troponin and the inflammatory markers: TNF- $\alpha$, IL-1 and c-reactive protein (CRP). Patients were also classified according to the TIMI risk score in accordance with Antman et al. [4].

The second group consisted of 50 patients (mean age $58.0 \pm 18.9$ ) admitted to the RHP with others cardiac disease, but not ACS. Patients with or without ACS on anti-inflammatory drugs treatment, with recent trauma, infectious process or cancer were excluded from this study. Data on the presence of risk factors for ACS, such as diabetes mellitus, systemic arterial hypertension and smoking were collected from the hospital records of the patients.

A group of 295 individuals (mean age $47.3 \pm 7.9$ ), blood donors from the Fundação de Hematologia e Hemoterapia de Pernambuco (Hemope) were formed to investigate the frequency of genetic polymorphisms in a healthy population [15]. Individuals with positive serology for HIV, Chagas disease, Hepatitis C, Syphilis and HTLV 1/2 were excluded.

Ethics Committee of RHP approved the study (CAAE 03187512.2.0000.5202) and all participants signed informed consent forms.

\subsection{Genotyping}

DNA extraction was performed with "illustra genomicPrep blood Mini Spin kit" and the amplification of genes fragments was done by 
Table 2

Distribution of diabetes and hypertension in Thrombolysis in Myocardial Infarction (TIMI) risk.

\begin{tabular}{llllll}
\hline Risk factors & $\begin{array}{l}\text { Low risk } \\
\mathrm{n}=70 \mathrm{n} \\
(\%)\end{array}$ & $\begin{array}{l}\text { Intermediate + High risk } \\
\mathrm{n}=130 \mathrm{n}(\%)\end{array}$ & $\mathrm{p}^{*}$ & OR & CI 95\% \\
\hline Diabetes & $24(34.3)$ & $67(51.5)$ & 0.05 & 1.84 & $0.99-3.44$ \\
Hypertension & $46(65.7)$ & $111(85.4)$ & 0.003 & 2.92 & $1.43-5.97$
\end{tabular}

Legend: $\mathrm{n}$ : patients number; $\mathrm{p}^{*}$ : multivariate logistic regression; OR: Odds ratio, CI: Confidence Interval.

polymerase chain reaction (PCR) with Platinum Taq DNA polymerase (Invitrogen Life Technologies). The fragments were, then, visualized on $1 \%$ agarose gel. Genotyping of $L E P R, T N F a$ and $I L 1 b$ were done through DNA sequencing at Núcleo de Plataformas Tecnológicas from Centro de Pesquisas Aggeu Magalhães (CPqAM), using the ABI 3500xL Genetic Analyzer (Applied Biosystems, USA). IL6R was genotyped by Restriction Fragment Length Polymorphism (RFLP) with the enzyme BsaHI (New England Biolabs ${ }^{\circledR}$ ) (Table 1).

\subsection{Cytokine quantification}

Cytokines levels (TNF- $\alpha$ and IL1) were measured in patient's serum by enzyme linked immunosorbent assay (ELISA; Quantikine kit R\&D Systems, Minneapolis, MN) according to manual instructions.

\subsection{Statistical analysis}

Chi-square test $\left(\chi^{2}\right)$ was used to verify the Hardy-Weinberg equilibrium. Differences in genotype and allele frequencies between groups were compared using Williams G test. Odds ratios (ORs) and 95\% confidence interval (CI) were also calculated to determine if genotype frequencies are involved with the TIMI score and myocardial injury markers. To compare the variation of cytokine concentrations among groups, the Kruskal-Wallis or Mann-Whitney test were used. A Multinomial logistic regression was used, with low risk TIMI as a reference, to compare genotype and allelic distribution among the TIMI score. Data were considered statistically significant when $\mathrm{p}$ value $<$ 0.05. BioEstat software version 5.3 [20] was used.

\section{Results and discussion}

The male gender was the most frequent in the three groups evaluated: $76.5 \%$ (ACS patients), $56.0 \%$ (without ACS) and $82.7 \%$ (blood donors). Male gender mean age with ACS $(60.1 \pm 12.3)$ and without ACS (54.6 \pm 17.1$)$ was lower than that for women (67.5 \pm 14.3 with ACS and $61.4 \pm 20.7$ without ACS). According to Overbaugh (2009) [21], mean age considered risk for ACS begins in 45 years for men and 55 for women, which is in agreement with our results. In addition, men often have coronary heart disease earlier than women in part because of the increased exposure of men to some risk factors for heart diseases, such as smoking and obesity. Besides, the female hormone estrogen has protective effect, since it works as a blood pressure regulator and vascular lumen narrowing inhibitor [22].

Most of the studied participants in both ACS and non-ACS groups were non-smokers $(69.5 \%$ and $82.0 \%$, respectively; $\mathrm{p}=0.003)$ and non-diabetic $(54.5 \%$ and $68.0 \%$, respectively; $\mathrm{p}=0.01)$. Similarly, Bray et al. [23], studying Australian patients with ACS found that the majority were non-smokers (64.0\%) and had no diabetes $(74.0 \%)$. Nevertheless, the importance of these two components cannot be excluded as risk factors for cardiovascular diseases, but it reinforces the fact that this disease has a multifactorial characteristic.

The smoke contains oxidizing components that can lead to endothelial dysfunction and injury, initiating the atherosclerotic process. They also favor platelet aggregation, atherosclerotic plaque rupture and fibrinolytic capacity decrease [24]. Futhermore, cardiovascular disease is the most prevalent cause of morbidity and mortality among people with type 1 or type 2 diabetes [25]. Usually, most patients with diabetes have other comorbidities (obesity, hypertension and dyslipidemias) that together increase the risk for cardiovascular diseases [26].

Most ACS (78.5\%) and non-ACS (64.0\%) patients from this study had hypertension, but only those in the first group presented dyslipidemia (63.0\%). Some studies $[23,27,28]$ involving patients with ACS from different countries (Australia, Pakistan, and Mexico) also found that hypertension rates were 59.0\% in Australia, 61.1\% in Pakistan and $68.0 \%$ in Mexico patients, similar to those found in the non-ACS group (64.0\%) and slightly lower than in the ACS group (78.5\%) from the present study. According to Kannel et al. [29], hypertension is a powerful predictor of coronary disease. The studies of Bray et al. [23] and Vargas-Alarcon et al. [27] found that $62.0 \%$ and $52.0 \%$ of patients with ACS, respectively, had dyslipidemias, as in the present study. The participation of hypercholesterolemia as a risk factor for cardiovascular diseases is well established. Angiographic studies have demonstrated that the reduction of blood cholesterol levels slows the progression of atherosclerosis and may even induce its regression [30,31].

From ACS group, 70 patients (35\%) presented low, 89 (44.5\%) intermediate and $41(20.5 \%)$ high risk of death, according to TIMI classification. For the logistic regression, the intermediate and high risks were compared to the low risk. The four risk factors (smoking, diabetes, hypertension, dyslipidemias) were assessed according to the severity of the TIMI risk in a simple logistic regression model. Diabetes and hypertension presented $\mathrm{p}$ value $<0.2$ and were selected for multivariate logistic regression. It was then observed that the variable hypertension was related to worsening of the classification $(p=0.003)$, most of the hypertensive patients (85.4\%) were classified as intermediate or high TIMI risk, so this risk factor is also related to the severity of the TIMI risk (Table 2).

Genotyping of the samples showed that the genes were in HardyWeinberg equilibrium ( $p>0.05$ ). The most frequent genotype for the IL6R was CC $(51.5 \%$ in ACS patients, $40.0 \%$ in non-ACS patients and $49.5 \%$ in the blood donors group) with a higher proportion of TT genotype in blood donors (32.2\%) than in ACS patients $(18.0 \%$; $\mathrm{p}=0.0002$ ) (Table 3). This fact was also observed in a study by Elliot et al. (2009), which showed that the lower frequency $\mathrm{T}$ allele decreases the risk of coronary diseases development.

For TNFa gene, the most frequent genotype was GG $73.5 \%$ in ACS patients, $74.0 \%$ in non-ACS patients and $75.3 \%$ in the blood donnors group) ( $\mathrm{p}=0.01$ ), with statistical differences among groups (Table 3 ). For this gene, Zhang et al. [32] found that the A allele is more present in patients with ACS than in healthy individuals in Caucasian populations but not in Asian, African or Indian populations. Studies [17,32] that point to the A allele in susceptibility to coronary disease state that this allele is associated to higher serum cytokine levels in relation to $\mathrm{G}$ allele. However, serum TNF-a levels in our samples did not show any difference among genotypes, neither between patients and the blood donors.

Regarding the LEPR gene, the highest frequency genotype was CT (49.0\% in patients with ACS, $58.0 \%$ in non-ACS and $51.9 \%$ in blood donors group) with no significant differences among groups. In $I L 1 b$ gene, the most found genotype was CT (52.0\% in ACS patients, $46.0 \%$ in non-ACS patients and $46.8 \%$ in the blood donors group), also with no statistical differences among groups (Table 3). Serum IL-1 levels were not influenced by the genotypes in the analyzed samples.

When ACS patients were stratified according to TIMI risk, there was no differences in the genotypic distributions of TNF- $a, L E P R$ and ILIb. However, the TT genotype in IL6R were different between low and high risk groups ( $\mathrm{OR}=5.55, \mathrm{p}=0.03$ ) and between intermediate and high risk groups $(\mathrm{OR}=5.35, \mathrm{p}=0.04)$ (Table 4$)$. This genotype was more frequent in patients with low $(22.9 \%)$ than in intermediate $(20.2 \%)$ and high (4.9\%) TIMI risks (data not shown). These results, combined with the literature data, show a possible protective role of the TT genotype in 
Table 3

Genotype frequencies in the three studied groups.

\begin{tabular}{|c|c|c|c|c|c|}
\hline GENOTYPES & $\begin{array}{l}\text { ACS }(\mathrm{n}=200) \\
\mathrm{n}(\%)\end{array}$ & $\begin{array}{l}\text { Non-ACS }(\mathrm{n}=50) \\
\mathrm{n}(\%)\end{array}$ & $\begin{array}{l}\text { ACS } \times \text { Non-ACS } \\
\mathrm{p}\end{array}$ & $\begin{array}{l}\text { Blood donnors }(\mathrm{n}=295) \\
\mathrm{n}(\%)\end{array}$ & $\begin{array}{l}\text { ACS } \times \text { Blood donnors } \\
\mathrm{p}\end{array}$ \\
\hline \multicolumn{6}{|c|}{ IL6R $(c 950-1722 C>T)$} \\
\hline $\mathrm{CC}$ & $103(51.5)$ & $20(40.0)$ & 0.29 & $146(49.5)$ & 0.0002 \\
\hline CT & $61(30.5)$ & $17(34.0)$ & & $54(18.3)$ & \\
\hline TT & $36(18.0)$ & $13(26.0)$ & & $95(32.2)$ & \\
\hline $\mathrm{CC}+\mathrm{CT}$ & $164(82.0)$ & $37(74.0)$ & 0.21 & $200(67.8)$ & 0.0004 \\
\hline \multicolumn{6}{|l|}{ Alleles } \\
\hline $\mathrm{C}$ & $267(66.8)$ & $57(57.0)$ & & $346(58.6)$ & \\
\hline $\mathrm{T}$ & $133(33.2)$ & $43(43.0)$ & & $244(41.3)$ & \\
\hline \multicolumn{6}{|c|}{ TNFa $(c .-488 G>A)$} \\
\hline GG & $147(73.5)$ & $37(74.0)$ & 0.06 & $222(75.3)$ & 0.01 \\
\hline GA & $52(26.0)$ & $10(20.0)$ & & $61(20.7)$ & \\
\hline $\mathrm{AA}$ & $01(0.5)$ & $03(6.0)$ & & $12(4.0)$ & \\
\hline $\mathrm{GG}+\mathrm{GA}$ & $199(99.5)$ & $47(94.0)$ & 0.03 & $283(95.9)$ & 0.007 \\
\hline \multicolumn{6}{|l|}{ Alleles } \\
\hline G & $346(86.5)$ & $84(84)$ & & $505(85.6)$ & \\
\hline A & $54(13.5)$ & $16(16)$ & & $85(14.4)$ & \\
\hline \multicolumn{6}{|c|}{ LEPR $(c .2673+1118 C>T)$} \\
\hline $\mathrm{CC}$ & $77(38.5)$ & $14(28.0)$ & 0.19 & $96(32.5)$ & 0.33 \\
\hline CT & $98(49.0)$ & $29(58.0)$ & & $153(51.9)$ & \\
\hline $\mathrm{TT}$ & $25(12.5)$ & $07(14.0)$ & & $46(15.6)$ & \\
\hline $\mathrm{CC}+\mathrm{CT}$ & 175 (87.5) & $43(86.0)$ & 0.78 & $249(84.4)$ & 0.33 \\
\hline \multicolumn{6}{|l|}{ Alleles } \\
\hline $\mathrm{C}$ & $252(63.0)$ & $57(57)$ & & $345(58.5)$ & \\
\hline $\mathrm{T}$ & $148(37.0)$ & $43(43)$ & & 245 (41.5) & \\
\hline \multicolumn{6}{|c|}{$I L 1 b(c .-598 T>C)$} \\
\hline $\mathrm{CC}$ & $57(28.5)$ & $18(36.0)$ & 0.60 & $91(30.8)$ & 0.51 \\
\hline CT & $104(52.0)$ & $23(46.0)$ & & $138(46.8)$ & \\
\hline TT & 39 (19.5) & $9(18.0)$ & & $66(22.4)$ & \\
\hline $\mathrm{CC}+\mathrm{CT}$ & $161(80.5)$ & $41(82.0)$ & 0.06 & $229(77.6)$ & 0.58 \\
\hline \multicolumn{6}{|l|}{ Alleles } \\
\hline C & $218(54.5)$ & 59 (59) & & $320(54.2)$ & \\
\hline $\mathrm{T}$ & $182(45.5)$ & $41(41)$ & & $270(45.8)$ & \\
\hline
\end{tabular}

Legend: n: number of individuals; p: p-value $<0.05$ (Williams-G test).

IL6R against ACS.

According to Elliot et al., the T allele in $I L 6 R$ is related to increased expression of the soluble IL6 receptor (sIL6R) at the same time as it causes changes in the membrane receptor that couples the IL-6/sIL6R complex. The increase of sIL6R performs a negative feed-back in the receptors expression on antigen-presenting cells, rendering the inflammatory effects of IL-6.

The relationship between the $\mathrm{T}$ allele in this gene and coronary heart disease can be further explained by the close relationship between its presence and CRP levels. The inflammatory process is so important in ACS that PcR predicts greater severity to the patient when increased in its concentration, once it is implicated in development and

Table 4

Association between polymorphisms and different TIMI risk scores.

\begin{tabular}{|c|c|c|c|c|c|c|c|c|c|}
\hline \multirow[t]{2}{*}{ Genotype } & \multicolumn{3}{|c|}{ Low $\times$ Intermediate } & \multicolumn{3}{|c|}{ Low $\times$ High } & \multicolumn{3}{|c|}{ Intermediate $\times$ High } \\
\hline & OR & CI 95\% & $\mathrm{p}^{* * *}$ & OR & IC95\% & $\mathrm{p}^{* * *}$ & OR & CI $95 \%$ & $\mathrm{p}^{* * k}$ \\
\hline \multicolumn{10}{|c|}{$\operatorname{IL6R}(c 950-1722 \mathrm{C}>\mathrm{T})$} \\
\hline $\mathrm{CC}$ & 1 & - & - & 1 & - & - & 1 & - & - \\
\hline $\mathrm{CT}$ & 0.72 & $0.34-1.51$ & 0.50 & 0.89 & $0.37-2.12$ & 0.97 & 1.23 & $0.54-2.76$ & 0.76 \\
\hline TT & 1.03 & $0.46-2.32$ & 0.90 & 5.55 & $1.17-26.3$ & 0.03 & 5.35 & $1.14-25.05$ & 0.04 \\
\hline $\mathrm{CC}+\mathrm{CT}$ & 0.88 & $0.50-1.56$ & 0.78 & 0.96 & $0.49-1.85$ & 0.96 & 1.08 & $0.57-2.00$ & 0.92 \\
\hline \multicolumn{10}{|c|}{$T N F a(c .-488 G>A)$} \\
\hline GG & 1 & - & - & 1 & - & - & 1 & - & - \\
\hline GA & 0.93 & $0.46-1.89$ & 0.99 & 1.53 & $0.60-3.91$ & 0.49 & 1.63 & $0.66-4.02$ & 0.38 \\
\hline AA & - & - & - & - & - & - & - & - & - \\
\hline \multicolumn{10}{|c|}{$\operatorname{LEPR}(c .2673+1118 C>T)$} \\
\hline $\mathrm{CC}$ & 1 & - & - & 1 & - & - & 1 & - & - \\
\hline CT & 0.65 & $0.33-1.28$ & 0.28 & 0.87 & $0.38-1.97$ & 0.91 & 1.34 & $0.60-2.98$ & 0.59 \\
\hline $\mathrm{TT}$ & 0.46 & $0.16-1.32$ & 0.23 & 0.95 & $0.24-3.75$ & 0.77 & 2.05 & $0.58-7.24$ & 0.40 \\
\hline \multicolumn{10}{|l|}{$\mathrm{CC}+\mathrm{CT}$} \\
\hline \multicolumn{10}{|c|}{$\operatorname{IL1b}(c .-598 T>C)$} \\
\hline $\mathrm{CC}$ & 1 & - & - & 1 & - & - & 1 & - & - \\
\hline $\mathrm{CT}$ & 1.28 & $0.62-2.67$ & 0.62 & 0.97 & $0.39-2.38$ & 0.86 & 1.25 & $0.52-2.97$ & 0.77 \\
\hline TT & 1.47 & $0.63-3.39$ & 0.49 & 0.95 & $0.32-2.82$ & 0.84 & 0.83 & $0.28-2.45$ & 0.95 \\
\hline $\mathrm{CC}+\mathrm{CT}$ & & & & & & & & & \\
\hline
\end{tabular}


progression of atherosclerosis, influencing the maintenance of inflammation, vascular plaque development and endothelial injury during ACS [33].

Reinforcing these data, Swerdlow et al. [34] proved the evidence of the relationship between IL6R, CRP and ACS. Using a licensed monoclonal antibody for the treatment of rheumatoid arthritis, IL6R signaling was blocked and consequently decreased levels of CRP and the inflammatory process. These authors suggest, then, that $I L 6 R$ blockade can be used as a therapeutic target in the prevention of coronary diseases.

In agreement with these findings, our results show that patients with ACS and TT genotype were related to lower levels of CRP $(0.69 \mathrm{pg} /$ $\mathrm{mL}$ ) than in the other two genotypes $(\mathrm{p}=0.03)$ (data not shown). Also, patients in high TIMI score had higher CRP levels $(2.075 \mathrm{pg} / \mathrm{mL})$ than in the low TIMI score group $(0.795 \mathrm{pg} / \mathrm{mL})$, indicating a tendency of association between the CRP and the TIMI risk score $(p=0.05)$.

The diagnostic method of ACS, besides the physical evaluation and the electrocardiogram, involves the evaluation of mainly two markers of myocardial lesion, represented by troponin and CK-MB. In the present study, the majority of patients presented alterations in the serum levels of these two cardiac enzymes $83.0 \%$ for troponin and $60.0 \%$ for CK-MB). In this case, the other patients with normal values presented symptoms compatible with AI, since this condition does not result in blood changes of enzymes in myocardial injury. Most patients (54.8\%) who had altered troponin levels had CC genotype in IL6R (rs 4537545) (data not shown).

Noting the fact that the CC genotype in this gene is linked to higher levels of CRP, that this molecule is an inflammatory process marker and that this process is related to lesions in cardiac tissue, it is understandable, then, that this same genotype is related to elevated serum troponin levels. The other variants studied didńt show any association with serum troponin or CK-MB levels.

Due to the deficiency of studies in the literature relating genetic variants and markers of myocardial injury, a more comprehensive discussion needs to be done.

\section{Conclusions}

Hypertension and dyslipidemia were the two most prevalent risk factors in patients with ACS, suggesting that a prevention of these factors could contribute to a decrease in the atherosclerotic process. Hypertension showed association with the TIMI risk score, since the number of hypertensives in the TIMI intermediate/high score was statistically higher than in the low score, contributing to identify this risk factor as an important predictor of cardiovascular disease.

TT genotype in $I L 6 R$ was more frequent in blood donors $(32.2 \%)$ than in patients $(18.0 \%)$, and was more present in the low TIMI risk than in the intermediate and high TIMI risks. This genotype was also related to lower levels of CRP, in addition to a lower dosage of troponin, facts that may explain its possible protection against the ACS development and myocardial injury.

\section{Acknowledgements}

The authors thank the core-facilities laboratories of Instituto Aggeu Magalhães, Fundação Oswaldo Cruz (Fiocruz - PE) for the use of its technology.

\section{Funding sources}

This study was funded by Proep APQ 1620 4.01/15.

Conflict of interests

The authors declare that there are no conflicts of interest.

\section{References}

[1] Y. Birnbaum, J.M. Wilson, M. Fiol, A.B. de Luna, M. Eskola, K. Nikus, ECG diagnosis and classification of acute coronary syndromes, Annals Noninvasive Electrocard. 19 (1) (2014) 4-14.

[2] F. Crea, G. Liuzzo, Pathogenesis of acute coronary syndromes, J. Am. Coll. Cardiol. 61 (1) (2013) 1-11.

[3] C.W. Hamm, J.P. Bassand, S. Agewall, J. Bax, E. Boersma, H. Bueno, P. Caso, D. Dudek, S. Gielen, K. Huber, M. Ohman, M.C. Petrie, F. Sonntag, M.S. Uva, R.F. Storey, W. Wijns, D. Zahger, Esc, ESC Guidelines for the management of acute coronary syndromes in patients presenting without persistent ST-segment elevation, Eur. Heart J. 32 (23) (2011) 2999-3054.

[4] E.M. Antman, D.T. Anbe, P.W. Armstrong, E.R. Bates, L.A. Green, M. Hand, J.S. Hochman, H.M. Krumholz, F.G. Kushner, G.A. Lamas, C.J. Mullany, J.P. Ornato, D.L. Pearle, M.A. Sloan, S.C. Smith, E.M. Antman, S.C. Smith, J.S. Alpert, J.L. Anderson, D.P. Faxon, V. Fuster, R.J. Gibbons, G. Gregoratos, J.L. Halperin, L.F. Hiratzka, S.A. Hunt, A.K. Jacobs, J.P. Ornato, ACC/AHA guidelines for the management of patients with ST-elevation myocardial infarction - executive summary - a report of the American College of Cardiology American Heart Association task force on practice guidelines - (Writing committee to revise the 1999 guidelines for the management of patients with acute myocardial infarction), Can. J. Cardiol. 20 (10) (2004) 977-1025.

[5] D.L.S. Rios, C.C.S. Cerqueira, R. Bonfim-Silva, L.J. Araujo, J.F. Pereira, S.R. Gadelha, A.A.L. Barbosa, Interleukin-1 beta and interleukin-6 gene polymorphism associations with angiographically assessed coronary artery disease in Brazilians, Cytokine 50 (3) (2010) 292-296.

[6] A.C. Tonet, M. Karnikowski, C.F. Moraes, L. Gomes, M.G.O. Karnikowski, C. Cordova, O.T. Nobrega, Association between the-174 G/C promoter polymorphism of the interleukin-6 gene and cardiovascular disease risk factors in Brazilian older women, Braz. J. Med. Biol. Res. 41 (1) (2008) 47-53.

[7] M. Franchini, F. Peyvandi, P.M. Mannucci, The genetic basis of coronary artery disease: from candidate genes to whole genome analysis, Trends Cardiovasc. Med. 18 (5) (2008) 157-162.

[8] B.M. Babu, B.P. Reddy, V.H. Priya, A. Munshi, H.S. Rani, G.S. Latha, V.D. Rao, A. Jyothy, Cytokine gene polymorphisms in the susceptibility to acute coronary syndrome, Genet Test Mol Biomarkers 16 (5) (2012) 359-365.

[9] W.T. Chang, Y.C. Wang, C.C. Chen, S.K. Zhang, C.H. Liu, F.H. Chang, L.S. Hsu, The308G/A of tumor necrosis factor (TNF)-alpha and 825C/T of Guanidine Nucleotide Binding Protein 3 (GNB3) are associated with the onset of acute myocardial infarction and obesity in Taiwan, Int. J. Mol. Sci. 13 (2) (2012) 1846-1857.

[10] P. Elliott, J.C. Chambers, W. Zhang, R. Clarke, J.C. Hopewell, J.F. Peden, J. Erdmann, P. Braund, J.C. Engert, D. Bennett, L. Coin, D. Ashby, I. Tzoulaki, I.J. Brown, S. Mt-Isa, M.I. McCarthy, L. Peltonen, N.B. Freimer, M. Farrall, A. Ruokonen, A. Hamsten, N. Lim, P. Froguel, D.M. Waterworth, P. Vollenweider, G. Waeber, M.R. Jarvelin, V. Mooser, J. Scott, A.S. Hall, H. Schunkert, S.S. Anand, R. Collins, N.J. Samani, H. Watkins, J.S. Kooner, Genetic Loci associated with Creactive protein levels and risk of coronary heart disease, JAMA 302 (1) (2009) $37-48$.

[11] O. Ozdemir, F. Gundogdu, S. Karakelleoglu, S. Sevimli, I. Pirim, M. Acikel, S. Arslan, S. Serdar, Comparison of serum levels of inflammatory markers and allelic variant of interleukin-6 in patients with acute coronary syndrome and stable angina pectoris, Coron. Artery Dis. 19 (1) (2008) 15-19.

[12] M.P. Sie, F.A. Sayed-Tabatabaei, H.H. Oei, A.G. Uitterlinden, H.A. Pols, A. Hofman, C.M. van Duijn, J.C. Witteman, Interleukin 6-174 g/c promoter polymorphism and risk of coronary heart disease: results from the rotterdam study and a meta-analysis, Arterioscler Thromb. Vasc. Biol. 26 (1) (2006) 212-217.

[13] M. Hedayati, K. Sharifi, F. Rostami, M.S. Daneshpour, M.Z. Yeganeh, F. Azizi, Association between TNF-alpha promoter G-308A and G-238A polymorphisms and obesity, Mol. Biol. Rep. 39 (2) (2012) 825-829.

[14] J.G. Stegger, E.B. Schmidt, A. Tjonneland, T.I. Kopp, T.I.A. Sorensen, U. Vogel, K. Overvad, Single nucleotide polymorphisms in IL1B and the risk of acute coronary syndrome: a Danish case-cohort study, Plos One 7 (6) (2012).

[15] V.C.V. Carvalho, M.J.R. Bezerra, L.C.A. Silva, A.J.M. Silva, F.C.S. Soares, S.A.V. Oliveira, R.P. Werkhauser, C.G.R. Silva, C.N.L. Morais, A.V. Gomes, S.M.L. Montenegro, Polymorphisms associated with acute coronary syndrome, Biomark. Applicat. 2017 (01) (2017) 1-6.

[16] S.A.V. Oliveira, Desenvolvimento de métodos para genotipagem de polimorfismos no gene do receptor de citocina IL-6 e receptor de leptina em pacientes com Síndrome Coronariana Aguda, Departamento de Imunologia, Universidade Federal de Pernambuco, Recife - PE, 2013.

[17] M.M. Elahi, A. Gilmour, B.M. Matata, S.S. Mastana, A variant of position-308 of the tumour necrosis factor alpha gene promoter and the risk of coronary heart disease, Heart Lung Circul. 17 (1) (2008) 14-18.

[18] M. Swellam, N. Hamdy, Association of nonalcoholic fatty liver disease with a single nucleotide polymorphism on the gene encoding leptin receptor, IUBMB Life 64 (2) (2012) 180-186.

[19] B. Vohnout, A. Di Castelnuovo, R. Trotta, A. D'Orazi, G. Panniteri, A. Montali, M.B. Donati, M. Arca, L. Iacoviello, Interleukin-1 gene cluster polymorphisms and risk of coronary artery disease, Haematologica 88 (1) (2003) 54-60.

[20] M. Ayres, M. Ayres Jr., D.L. Ayres, S. AA, BioEstat5.0: aplicações estatísticas nas áreas das ciências biomécias. , Belem (PA): Brasil, 2007, pp. 1-324.

[21] K.J. Overbaugh, Acute coronary syndrome, Am. J. Nurs. 109 (5) (2009) 42-52 quiz 53.

[22] M.E. Mendelsohn, R.H. Karas, The protective effects of estrogen on the cardiovascular system, N. Engl. J. Med. 340 (23) (1999) 1801-1811. 
[23] J.E. Bray, D. Stub, P. Ngu, S. Cartledge, L. Straney, M. Stewart, W. Keech, H. Patsamanis, J. Shaw, J. Finn, Mass media campaigns' influence on prehospital behavior for acute coronary syndromes: an evaluation of the Australian Heart Foundation's warning signs campaign, J. Am. Heart Assoc. 4 (7) (2015).

[24] A. Csordas, D. Bernhard, The biology behind the atherothrombotic effects of cigarette smoke, Nat. Rev. Cardiol. 10 (4) (2013) 219-230.

[25] G. Orasanu, J. Plutzky, The pathologic continuum of diabetic vascular disease, J. Am. Coll. Cardiol. 53 (5 Suppl) (2009) S35-S42.

[26] M. AlGhatrif, Y.F. Kuo, S. Al Snih, M.A. Raji, L.A. Ray, K.S. Markides, Trends in hypertension prevalence, awareness, treatment and control in older Mexican Americans, 1993-2005, Ann. Epidemiol. 21 (1) (2011) 15-25.

[27] G. Vargas-Alarcon, M. Vallejo, C. Posadas-Romero, J.G. Juarez-Rojas, M.A. Martinez-Rios, M.A. Pena-Duque, S. Carrillo-Sanchez, O. Perez-Mendez J.M. Fragoso, The -974C > A (rs3087459) gene polymorphism in the endothelin gene (EDN1) is associated with risk of developing acute coronary syndrome in Mexican patients, Gene 542 (2) (2014) 258-262.

[28] H.S. Satti, S. Hussain, Q. Javed, Association of interleukin-6 gene promoter polymorphism with coronary artery disease in Pakistani families, Sci. World J., 2013.

[29] W.B. Kannel, T.R. Dawber, D.L. McGee, Perspectives on systolic hypertension. The Framingham study, Circulation 61 (6) (1980) 1179-1182.

[30] W.P. Castelli, R.J. Garrison, P.W. Wilson, R.D. Abbott, S. Kalousdian, W.B. Kannel, Incidence of coronary heart disease and lipoprotein cholesterol levels. The Framingham study, JAMA 256 (20) (1986) 2835-2838.

[31] L. Lacoste, J.Y. Lam, J. Hung, G. Letchacovski, C.B. Solymoss, D. Waters, Hyperlipidemia and coronary disease. Correction of the increased thrombogenic potential with cholesterol reduction, Circulation 92 (11) (1995) 3172-3177.

[32] H.F. Zhang, S.L. Xie, J.F. Wang, Y.X. Chen, Y. Wang, T.C. Huang, Tumor necrosis factor-alpha G-308A gene polymorphism and coronary heart disease susceptibility: an updated meta-analysis, Thromb. Res. 127 (5) (2011) 400-405.

[33] A. Kumar, C.P. Cannon, Acute coronary syndromes: diagnosis and management, part II, Mayo Clin. Proc. 84 (11) (2009) 1021-1036.

[34] D.I. Swerdlow, M.V. Holmes, K.B. Kuchenbaecker, J.E. Engmann, T. Shah, R. Sofat, Y. Guo, C. Chung, A. Peasey, R. Pfister, S.P. Mooijaart, H.A. Ireland, M. Leusink, C. Langenberg, K.W. Li, J. Palmen, P. Howard, J.A. Cooper, F. Drenos, J. Hardy, M.A. Nalls, Y.R. Li, G. Lowe, M. Stewart, S.J. Bielinski, J. Peto, N.J. Timpson, J. Gallacher, M. Dunlop, R. Houlston, I. Tomlinson, I. Tzoulaki, J. Luan, J.M. Boer, N.G. Forouhi, N.C. Onland-Moret, Y.T. van der Schouw, R.B. Schnabel,

J.A. Hubacek, R. Kubinova, M. Baceviciene, A. Tamosiunas, A. Pajak, R. ToporMadry, S. Malyutina, D. Baldassarre, B. Sennblad, E. Tremoli, U. de Faire, L. Ferrucci, S. Bandenelli, T. Tanaka, J.F. Meschia, A. Singleton, G. Navis, I. Mateo Leach, S.J. Bakker, R.T. Gansevoort, I. Ford, S.E. Epstein, M.S. Burnett, J.M. Devaney, J.W. Jukema, R.G. Westendorp, G. Jan de Borst, Y. van der Graaf, P.A. de Jong, A.H. Mailand-van der Zee, O.H. Klungel, A. de Boer, P.A. Doevendans, J.W. Stephens, C.B. Eaton, J.G. Robinson, J.E. Manson, F.G. Fowkes, T.M. Frayling, J.F. Price, P.H. Whincup, R.W. Morris, D.A. Lawlor, G.D. Smith, Y. Ben-Shlomo, S. Redline, L.A. Lange, M. Kumari, N.J. Wareham, W.M. Verschuren, E.J. Benjamin, J.C. Whittaker, A. Hamsten, F. Dudbridge, J.A. Delaney, A. Wong, D. Kuh, R. Hardy, B.A. Castillo, J.J. Connolly, P. van der Harst, E.J. Brunner, M.G. Marmot, C.L. Wassel, S.E. Humphries, P.J. Talmud, M. Kivimaki, F.W. Asselbergs, M. Voevoda, M. Bobak, H. Pikhart, J.G. Wilson, H. Hakonarson, A.P. Reiner, B.J. Keating, N. Sattar, A.D. Hingorani, J.P. Casas, The interleukin-6 receptor as a target for prevention of coronary heart disease: a mendelian randomisation analysis, Lancet 379 (9822) (2012) 1214-1224. 